\title{
Electoral Institutions and the Politics of Coalitions: Why Some Democracies Redistribute More Than Others
}

\author{
TORBEN IVERSEN Harvard University \\ DAVID SOSKICE Duke University, London School of Economics and Wissenschaftszentrum
}

Berlin

\begin{abstract}
Ttandard political economy models of redistribution, notably that of Meltzer and Richard (1981), fail to account for the remarkable variance in government redistribution across democracies. We develop a general model of redistribution that explains why some democratic governments are more prone to redistribute than others. We show that the electoral system plays a key role because it shapes the nature of political parties and the composition of governing coalitions, hence redistribution. Our argument implies (1) that center-left governments dominate under PR systems, whereas center-right governments dominate under majoritarian systems; and (2) that PR systems redistribute more than majoritarian systems. We test our argument on panel data for redistribution, government partisanship, and electoral system in advanced democracies.
\end{abstract}

W hy do some countries redistribute more than others? Most work on the politics of redistribution starts from the premise that democratic institutions empower those who stand to benefit from redistribution. The basic logic is succinctly captured in the Meltzer-Richard (1981) model, where the voter with the median income is also the decisive voter. With a typical right-skewed distribution of income, the median voter will push for redistributive spending up to the point where the benefit of such spending to the median voter is outweighed by the efficiency costs of distortionary taxation.

This argument implies that redistibution is much greater in democracies than in nondemocracies (at least of the right-authoritarian variety), and that, among the latter, inegalitarian societies redistribute more than egalitarian ones. There is some evidence to support the first implication, although it is disputed (see Ross 2005), but most of the variance in redistribution is probably within the same regime type. According to data from the Luxembourg Income Study, for example, the reduction in the poverty rate in United States as a result of taxation and transfers was $13 \%$ in 1994 , whereas the comparable figure for Sweden was $82 \%$ (the poverty rate is the percentage of households below $50 \%$ of the median income). To explain this variance, we have to look at political and economic differences

\footnotetext{
Torben Iversen is Professor, Department of Government, Harvard University, Cambridge, MA 02138.

David Soskice is Research Professor, Department of Political Science, Duke University, Durham, NC 27708.

An early version of this paper was presented at the 2002 Annual Meetings of the American Political Science Association, Sheraton and Marriott Hotels, Boston, August 29-September 2. We thank Jim Alt, Klaus Armingeon, Neal Beck, David Brady, Geoffrey Brennan, Gary Cox, Thomas Cusack, Jeff Frieden, Robert Goodin, Peter Hall, Peter Katzenstein, Daniel Kselman Robert Keohane, Herbert Kitschelt, Peter Lange, Philipp Rehm, Gerard Roland, Frances Rosenbluth, Fritz Scharpf, Ken Shepsle, Michael Wallerstein, anonymous reviewers, and the participants in the Workshop on the economic consequences of democratic institutions, Department of Political Science, Duke University, April 1-2, 2005 for their many helpful comments on a previous version of this paper.
}

among democracies, but the second implication-that inegalitarian societies redistribute more-turns out to be of little help. In fact the empirical relationship between inequality and redistribution is the opposite of the predicted one (see Bénabou 1996; Moene and Wallerstein 2001; Perotti 1996). Sweden not only redistributes more than the United States, but also is a much more egalitarian society. So the explanation for why some democracies redistribute more than others would seem to lie more or less wholly outside the standard framework in political economy to explain democratic redistribution.

One possibility is that the power of the working class and left political parties varies across countries (see, e.g., Korpi 1983, 1989; Hicks and Swank 1992; Huber and Stephens 2001). Because it is plausible that redistribution is a function of government policies, and such policies reflect the preferences of those who govern, looking for differences in government partisanship is a promising avenue. Furthermore, if left governments not only redistribute more but also reduce inequality of earnings by, say, investing heavily in public education, partisanship may also explain why equality and redistribution tend to co-vary. Indeed, there is much evidence to the effect that government partisanship helps explain cross-national differences in redistribution (Boix 1998; Bradley et al. 2003; Kwon and Pontusson 2003), and our finding corroborate this evidence. But it raises another puzzle: why are some democracies dominated by left governments, whereas others are dominated by right governments?

Although government partisanship is often assumed to reflect the level of working-class mobilization, we argue that it is in fact mainly determined by differences in coalitional dynamics associated with particular electoral systems. Table 1 shows the strong empirical relationship using a new dataset on parties and legislatures (see Cusack and Engelhardt 2002; Cusack and Fuchs 2002). The figures are the total number of years with right and left governments in 17 advanced democracies between 1945 and 1998, organized by type of electoral system. Mirroring a similar finding by Powell (2002), 


\begin{tabular}{|c|c|c|c|c|}
\hline & & \multicolumn{2}{|c|}{$\begin{array}{l}\text { Government } \\
\text { Partisanship }\end{array}$} & \multirow{2}{*}{$\begin{array}{c}\text { Proportion of } \\
\text { Right Governments }\end{array}$} \\
\hline & & Left & Right & \\
\hline \multirow[t]{2}{*}{$\begin{array}{r}\text { Electoral } \\
\text { system }\end{array}$} & Proportional & $\begin{array}{c}342 \\
(8)\end{array}$ & $\begin{array}{c}120 \\
(1)\end{array}$ & 0.26 \\
\hline & Majoritarian & $\begin{array}{l}86 \\
(0)\end{array}$ & $\begin{array}{c}256 \\
(8)\end{array}$ & 0.75 \\
\hline
\end{tabular}

about three fourths of governments in majoritarian systems were center-right, whereas three fourths of governments under PR were center-left (excluding here "pure" center governments). The numbers in parentheses convey a sense of the evidence at the level of countries, classifying countries according to whether they have an overweight (more than $50 \%$ ) of centerleft or center-right governments during the 194598 period. We discuss the data (and the one outlier) in detail next.

Our explanation for the association in Table 1 builds on an emerging literature on the effects of electoral formulae on economic policies and outcomes (see, e.g., Persson and Tabellini 1999, 2000, 2003; Rogowski and Kayser 2002; Austen-Smith 2000). In particular, we argue that the electoral formula affects coalition behavior and leads to systematic differences in the partisan composition of governments-hence, to different distributive outcomes. The model we propose assumes that parties represent classes, or coalition of classes, and that it is difficult for parties to commit credibly to electoral platforms that deviate from the preferences of their constituents. We also make a critical departure from standard models based on Meltzer-Richard (1981) by allowing taxes and transfers to vary across classes, thereby transforming redistributive politics into a multidimensional game. In particular, we move away from a simple rich-poor model to one in which the middle class will fear taxation by the poor, even as it faces an incentive to ally with the poor to take from the rich. The only constraint is that the rich cannot "soak" the middle class and poor under democracy-a condition that can be justified on empirical, normative, and institutional grounds.

Based on these very general assumptions we show that in a two-party majoritarian system the center-right party is more likely to win government power, and redistribute less, than in a multiparty PR system where the center party is more likely to ally with parties to its left. The intuition is that in a majoritarian system where parties cannot fully commit, the median voter faces low taxes if a center-right party deviates to the right if elected, but faces high taxes and redistribution to lowincome groups if a center-left party in government deviates to the left. With PR, on the other hand, the middleclass party has an incentive to form a coalition with the left party because they can together "exploit" the rich. No such exploitation of the poor is feasible under realistic assumptions. Remarkably, therefore, the same set of assumptions about redistributive policies leads to opposite predictions about government partisanship depending on the electoral system. We test the model on postwar data for redistribution and government partisanship for advanced democracies since the Second World War.

\section{THE MODEL}

We begin by explaining the assumptions of the model and then prove that these assumptions have two key implications: (1) that center-right governments are more frequent than center-left governments under majoritarian elections and redistribute less, and (2) that the obverse holds true for proportional representation (PR).

\section{General Assumptions}

As in many examples in Persson and Tabellini (1999) and in Acemoglu and Robinson (2005) we assume that individuals are members of one of three classes, indexed $J$. These are $L$, the low-income, $M$ the middleincome, and $H$ the high-income groups. The voting population is equally divided among the three groups and has a total size of 3 ; individuals cannot move between different groups.

We adopt a widely used economic model (e.g., in Persson, Roland, and Tabellini 2004) and write $J$ 's indirect utility function as

$$
V^{J}\left(p^{J}\right)=y^{J}-T^{J}+B^{J}=y^{J}+p^{J},
$$

where $y^{J}$ is the exogenous gross income of $J, T^{J}$ is a lump-sum tax on $J$, and $B^{J}$ is a government transfer to $J$. For convenience, we define $p^{J} \equiv B^{J}-T^{J}$, where $p^{J}$ is the net payment from the government to $J$; and from now on the paper drops explicit references to $B$ and $T$. Thus each group wants to maximize its net payment $p^{J}$ from the state.

Next we make the assumption that each group has a maximum taxable capacity (or minimum negative payoff) $\bar{T}^{J}<y^{J}$ and impose the taxable capacity constraint

$$
p^{J} \geq-\bar{T}^{J}
$$


Governments thus face a constraint in terms of how much they can tax any group. ${ }^{1}$ It is correspondingly assumed that

$$
0=\bar{T}^{L}<\bar{T}^{M}<\bar{T}^{H} .
$$

So the size of the maximum cake available for redistribution is $\bar{T} \equiv \bar{T}^{H}+\bar{T}^{M}$. In addition, the budget is balanced so that

$$
\sum_{J} p^{J}=0
$$

(Note that no assumption is made about the relation between median and average income-none of our results depend on that relationship.)

Assumptions (1) to (4) leave governments free to redistribute income among different classes in society, subject only to the taxable capacity and the budget constraints. But this ignores an important fact about advanced democracies: redistributive policies are with almost no exceptions at least mildly progressive. ${ }^{2}$ Indeed, Milanovic (2000) and Osberg, Smeeding, and Schwabisch (2003) show in detailed analyses of Luxembourg Income Study data on redistribution that the poor always gain from democratic redistribution, the rich always lose, whereas the middle class does less well than the poor but better than the rich. We therefore make the corresponding nonregressivity assumption:

$$
p^{L} \geq p^{M} \geq p^{H} .
$$

Note that this is weaker than the assumption commonly made of a proportional income tax and uniform benefit (as in the Meltzer-Richard (1981) model). In particular, it preserves the multidimensionality of the distributive space, so that there is no longer a simple median voter result. In our model, redistributive politics can only be understood as the result of class coalitions, where exclusion from the coalition carries a price. As we will see, allowing for such coalitions leads to very different conclusions from those of Meltzer-Richard.

The nonregressivity assumption, which imposes constraints on coalition behavior, can be justified on a number of grounds. As noted, it is an accurate empirical description, and it is common to assume that democratic governments are constrained by a basic notion of fairness (see, e.g., Roemer 2004). In our own view, assumption (5) can also be seen as reflecting the wider institutions of advanced democracies. These include a free press, free trade unions and other forms of association, the ability to demonstrate collectively, and so on. These wider institutions underwrite the ability of both lower and middle classes to take collective action if right wing domination of legislature and/or executive leads to attempts to exploit less privileged groups. This is an argument that needs elaboration and is the

\footnotetext{
${ }^{1}$ To simplify the accounting of resources, it is assumed that no resources are needed to collect taxes below $\bar{T}^{I}$ from group $I$, but that there is some high cost of setting higher taxes such that it does not pay a government to set taxes above $\bar{T}^{I}$.

${ }^{2}$ See the data from the Luxemburg Income Study (LIS) that we use later.
}

subject of future research. But we want to present it here, because it suggests a major difference between on the one hand, advanced democracies - in which these wider institutions play an important role-and, on the other hand, democracies in many developing countries where their role is subdued. ${ }^{3}$

Together, assumptions (1) through (5) imply that $L$ 's optimal policy is to tax $M$ and $H$ at their taxable capacity and keep all the receipts, $M$ 's optimal policy is to tax $H$ at its taxable capacity and share the receipts with $L$, whereas the best $H$ can do is not to tax (and redistribute) at all. The intuition behind all the results that follow is that the middle classes either ally with the poor for the purpose of soaking the rich (and splitting the booty) or ally with the rich for the purpose of avoiding being soaked by the poor. Which motive dominates, hence, which type of coalition is likely to emerge, depends on the electoral system. This explains why some democracies redistribute more than others as.

\section{Assumptions About Electoral Systems}

We now introduce electoral competition into the model and distinguish between proportional representation (PR) and majoritarian systems. We argue that each electoral system is associated with a distinct party system that in turn shapes the structure of class coalitions, and hence, redistribution. Throughout we assume that political parties are class (or group) parties that maximize the policy preferences of their constituents (as in, e.g., Hibbs 1977).

Proportional Representation. In a PR electoral system with three classes, where there is no institutional barrier to the representation of each, three class parties, $\boldsymbol{L}, \boldsymbol{M}$, and $\boldsymbol{H}$ (where bold italics indicate parties instead of classes) are assumed. Because parties under PR are perfect representatives of their constituents, we refer to them as representative parties. Decision making in a representative party $\boldsymbol{J}$ thus consists in maximizing group interests, namely, $p^{J}$.

If no party has a majority, as we assume, governments must be based on a coalition of two parties. The policies of the coalition are the result of bargaining, where one party, the "formateur," is recognized to make the first offer to another party of its choice. In coalition bargaining between $\boldsymbol{I}$ and $\boldsymbol{J}$, the bargained policy is a vector $P_{I J}=\left(p_{I J}^{L}, p_{I J}^{M}, p_{I J}^{H}\right)$, which is the result of splitting the pie $\bar{T}$ between $I$ and $J$ subject to the nonregressivity constraint (5). Common sense

\footnotetext{
${ }^{3}$ It is also interesting to consider this argument in light of Acemoglu and Robinson's (2005) work on the origins of democracy. They argue that democracy serves as a credible commitment mechanism by the rich to redistribute to the poor in order to fend off revolution (or to avoid excessive costs of repression). But democracy, in the narrow sense of free elections, cannot be a credible commitment, because redistribution follows from democracy only if government policies are subject to a nonregressivity constraint such as assumption (5) (see also Roemer 2004). We suspect that the collective-action capacities that underpin assumption (5) were developed before, rather than after, the transition to democracy.
} 
suggests that two parties would split the pie evenly (again, so long as (5) is satisfied), and this is precisely what Rubinstein bargaining theory predicts when parties exhibit equal degrees of impatience and the delay between offers goes to zero. So, for example, if $\boldsymbol{L}$ and $\boldsymbol{M}$ bargain with each other, they would each get $.5 \bar{T}$; because $M$ contributes $\bar{T}^{M}$ to $\bar{T}, M$ 's net transfer is $p_{L M}^{M}=.5 \bar{T}-\bar{T}^{M}=.5\left(\bar{T}^{H}-\bar{T}^{M}\right)>0 . \boldsymbol{H}$ is excluded from this coalition, so would lose $\bar{T}^{H}$. Thus, the policy vector in this case is $P_{L M}=\left[.5 \bar{T}, .5 \bar{T}-\bar{T}^{M},-\bar{T}^{H}\right]$.

The assumptions about PR electoral systems now can be summarized as follows:

(6) PR electoral systems. Under PR there are three representative parties, $\boldsymbol{L}, \boldsymbol{M}$, and $\boldsymbol{H}$. Policies are set by a majority coalition of two parties that is chosen by the party recognized as the formateur. The policy vector $P_{I J}=\left(p_{I J}^{L}, p_{I J}^{M}, p_{I J}^{H}\right)$ is the result of (Rubinstein) bargaining where the parties split the pie subject to the nonregressivity constraint (5).

Majoritarian System. Majoritarian systems work differently for reasons that are well understood in political science. First, as formalized in Duverger's Law, majoritarian systems can only sustain two parties in equilibrium. Because parties represent classes in our model, we therefore assume that there is one center-left, or $\boldsymbol{L M}$, party, and one center-right, or $\boldsymbol{M H}$, party. This conforms to the standard empirical observations of majoritarian systems with two major parties (at least in the advanced democracies we focus on here). ${ }^{4}$

There are now two different ways to think about how these parties determine what policy platform to run on. One is that $L$ and $M$ bargain a common policy in the $\boldsymbol{L M}$ party and that $M$ and $H$ bargain a common policy in the $\boldsymbol{M H}$ party. Such parties could sensibly be described as representative parties, because they reflect a compromise of their constituents' preferences. Correspondingly, the policies of each party in government would be equivalent to either an $\boldsymbol{L M}$ or an $\boldsymbol{M H}$ coalition in a PR system.

The obvious problem with this setup, however, has been recognized ever since Downs pointed it out nearly five decades ago (Downs 1957). Before either party in a majoritarian two-party system can implement their policies, they must win the election, and because $L$ will always vote $\boldsymbol{L M}$ and $H$ always $\boldsymbol{M H}$, winning is equivalent to getting the vote of $M$. Because representative parties would offer platforms that deviate significantly from the preferences of $M$, this implies that both parties have a strong incentive to try "moderate" their platforms to be more appealing to $M$. This is similar to Downs' median voter logic except that $M$ is not in fact a median in our model, given that there is more than one dimension. The importance of multidimensionality will become apparent in a moment.

For a party to cater to $M$, it has to organize itself in a manner that makes it plausible to $M$ voters that $M$-and not $L$ or $H$-is the group in whose interest

\footnotetext{
${ }^{4}$ It is of course also empirically true that there are often small third parties, but these are not important to our story as long as governments are always formed by one of the main parties.
}

policies are set. That means that the party has to shift power away from its rank-and-file to a leader who represents $M$. We refer to such parties as leadership parties: such parties are defined as giving decision-making power to the party leader.

But whereas such parties are clearly in a better position to capture the middle-class vote than representative parties, they cannot write legally binding contracts with voters to guarantee that they will (Persson and Tabellini 2000). After the election, there is always some chance that $L$ in $\boldsymbol{L M}$ and $H$ in $\boldsymbol{M H}$ will try, and succeed, in replacing the electoral platform with their own preferred policy. This tension between moderate leaders and their more radical internal rivals is widely recognized in the party literature (see, e.g., Aldrich 1993, 1995, ch. 6; Kitschelt 1991; Schlesinger 1984).

Needless to say, there will be very significant reputational costs of deviating from an $M$ platform. Leaders as well as rank-and-file understand this, and this is precisely why successful parties concentrate power in a moderate leader. But, again, the ability of the leader to control the party is contingent on postelection circumstances, and the mere possibility of a deviation has important implications for our story. Indeed this explains the focus of general elections in majoritarian systems on the perceived strength and moderation of the opposing leaders.

To model this in a very simple way, we assume that the probability that the leader of $\boldsymbol{L M}$ or of $\boldsymbol{M H}$ maximizes $p^{M}$ (the preference of $M$ ) is uniformly distributed between $\lambda$ and 1 prior to the election campaign. If $\lambda$ is high this is essentially saying that there is a high probability that a "moderate" $M$-leader will be chosen to control the party-the essence of a leadership party - but that there is a nontrivial risk that the leader may turn out to have $L$ preferences in the case of $\boldsymbol{L M}$, or $H$ preferences in the case of $\boldsymbol{M H}$, or at least be forced to accept them after the election. Voters learn about the extent of that risk during the election campaign, when much attention is on the rival party leaders. In a formal sense, this is equivalent to voters making a drawing $\left(\pi_{L M}, \pi_{M H}\right)$ from $(\lambda, 1) \times(\lambda, 1)$, where $\pi_{L M}$ and $\pi_{M H}$ are the updated probabilities that the leaders of $\boldsymbol{L M}$ and of $\boldsymbol{M H}$, respectively, maximize $p^{M} .5$

Summarizing our assumptions about majoritarian systems:

(7) Majoritarian electoral systems. Under majoritarian rules there are two leadership parties, $\boldsymbol{L} \boldsymbol{M}$ and $\boldsymbol{M H}$. Both parties present an $M$ platform in the election, but platforms are not legally binding. The probabilities that each party will implement the platform after the election are $\pi_{L M}$ and $\pi_{M H}$, respectively, which voters learn during the election campaign from a draw on $(\lambda, 1) \times(\lambda, 1)$. Voters vote strategically and the party with the most votes wins.

\footnotetext{
${ }^{5}$ It can be shown that if both $\boldsymbol{L M}$ and $\boldsymbol{M H}$ are representative parties, $\boldsymbol{M H}$ will always choose to become a leadership party; and if $\boldsymbol{M H}$ is a leadership party, $\boldsymbol{L M}$ will choose to become a leadership party as well, so long as $\lambda>1-\left[\bar{T}^{M} / \bar{T}^{H}\right]$. The proof is available from the authors.
} 


\begin{tabular}{|c|c|c|}
\hline & PR & Majoritarian \\
\hline Parties & $L, M, H$ & $L M, M H$ \\
\hline Party decision making & Representative & Leadership \\
\hline Platform commitment & Not problematic & Problematic \\
\hline Government & $\begin{array}{l}\text { Coalition of } \\
\text { parties }\end{array}$ & $\begin{array}{l}\text { Party as } \\
\text { coalition }\end{array}$ \\
\hline
\end{tabular}

The differences in the nature of political parties and government formation in PR and majoritarian electoral systems that we have explained in this section conform to both casual observation and systematic empirical evidence. In two party majoritarian systems parties focus, to an extent that is not true for parties under PR, on portraying themselves as centrist and their competitor as extremist. Correspondingly there is a systematic tendency for parties to take more distinct policy positions in PR than in majoritarian systems (Kedar 2003); and research on party organizations suggests that leaders in majoritarian systems are more important than those in PR systems (see Aarts, Blais and Schmitt, forthcoming).

Table 2 summarizes the discussion. It shows how the electoral system is linked to key aspects of the party system and the government formation process: (1) PR systems have three parties, whereas majoritarian systems only have two; (2) parties are representative under PR, but they are leadership parties under majoritarianism; (3) there is no problem of platform commitment under PR (all parties pursue the preferences of their constituents), whereas this is problematic in majoritarian systems because parties represent multiple constituents; and (4) the differences in parties is reflected in the government formation process where (to borrow a terminology from Bawn and Rosenblum, 2006) the government in a PR system is a coalition of parties, whereas the government in a majoritarian system is a coalition party.

A Citizen Candidate Interpretation of the Two Systems. It is useful to point out that our conception of party systems can be translated into the language of citizen candidate theory (Besley and Coate 1997; Osborne and Slivinski 1996). In citizen candidate models, citizens who run for office can only credibly represent themselves. In our model there are three groups of citizens, $L, M$, and $H$; and under PR, each party can be conceived as a citizen-candidate. With three candidates, no citizen has an incentive to run against any of these because they are perfectly representative, but there would be an incentive to replace a citizen candidate who dropped out. ${ }^{6}$ In our majoritarian two-party system, each party is composed of two types of citizens and the leader implements her own preferences. As

\footnotetext{
${ }^{6}$ Strictly speaking this requires each party to have a chance of affecting policies. As we show in a moment this requirement is satisfied if the formateur is randomly selected.
}

long as there is some probability that $L$ sets policies in the $\boldsymbol{L} \boldsymbol{M}$ party, and some probability that $H$ sets policies in the $\boldsymbol{M H}$ party, strategic voting will ensure that $\boldsymbol{L M}$ and $\boldsymbol{M H}$ are the only parties receiving votes. No citizen therefore has an incentive run against the established parties. The leadership party $\boldsymbol{I J}$ can thus be thought of as a citizen candidate about whose type the voter has incomplete information. ${ }^{7}$

\section{Implications for Partisanship and Redistribution}

In this section we show that assumptions (1) - (7) imply that center-right parties will win elections in majoritarian systems more of the time, whereas center-left coalitions will form governments in PR systems more of the time. Redistribution will be correspondingly lower under majoritarian rules. The same set of assumptions about group preferences and constraints on governments, (1) through (5), thus produces opposite predictions about redistributive politics when we move from one electoral system to another, given by assumptions (6) or (7). We begin with the majoritarian case and then turn to PR.

Majoritarian: Explaining the MH Bias. We will show in the majoritarian case that $M$ has more to fear from the prospect of the $\boldsymbol{L} \boldsymbol{M}$ party moving to the left in government than from the $\boldsymbol{M H}$ party moving to the right. Thus if the perceived odds of the leaders of both parties deviating are the same in any election, $M$ will vote for $\boldsymbol{M H}$. Given that on average over many elections leaders from each party will be perceived as equally likely to deviate from $M$ 's preferences, $M$ will therefore on average vote for $\boldsymbol{M H}$ rather than for $\boldsymbol{L M}$. Because $L$ will always vote $\boldsymbol{L M}$ (because there is some chance it will deviate to the left) and $H$ will always vote $\boldsymbol{M H}$ (because there is some chance it will deviate to the right), $M$ 's vote will determine the election.

The reason that $M$ is more worried about $\boldsymbol{L M}$ moving left than $\boldsymbol{M H}$ moving right is that there is nothing that prevents an $L$-dominated $\boldsymbol{L} \boldsymbol{M}$ government from taxing $M$ (and $H$ ) and redistributing it to low-income earners, whereas the best an $H$-dominated $\boldsymbol{M H}$ government can do for itself (given that it cannot pursue regressive policies) is to cut taxes and thereby redistribution to zero. Hence, under an $L$-dominated government, $M$ gets no benefits from the taxation of $H$, but is itself being taxed (for a net loss of $\bar{T}^{M}$ ). Under an $H$-dominated government, $M$ also loses all benefits, but now pays no taxes.

Although not designed to be a complete description of reality, the model captures what we see as an essential insight about redistribution under majoritarian rules. Because $M$ cannot write an enforceable contract with the government, it cannot be certain that an $\boldsymbol{L M}$ government will not defect to the left from an $M$

\footnotetext{
${ }^{7}$ With complete information an $M$ candidate can never run against another $M$ candidate since, with a cost of running, one would then drop out. But when there is incomplete information this is perfectly possible.
} 
platform and tax it without sharing the benefits. Middle-class voters will not like a right-wing government, but they have less to fear from it, because if it lowers taxes and spending below the preferred level, it also allows the middle classes to increase private spending. To both alternatives middle-class voters prefer being in the driver's seat, increasing taxes on higher income earners and benefiting in the form of redistribution. But if the chances of middle-class administrations from an $\boldsymbol{L} \boldsymbol{M}$ and an $\boldsymbol{M H}$ government are similar-and that is what $M$ assesses in the election- $M$ will feel more comfortable with an $\boldsymbol{M H}$ government. We stress that this does not mean that $\boldsymbol{M H}$ will always win because in any particular election $\boldsymbol{L M}$ may have a leader that is perceived to be sufficiently more likely to be moderate than the leader of $\boldsymbol{M H}{ }^{8}$

This logic can be expressed formally using the common assumptions (1) through (5) and the majoritarian system assumption (7). $\Pi_{M H}$ is defined as the ex-ante probability that $\boldsymbol{M H}$ will win. Ex-ante here means "before the election campaign has started," so that on assumption (7) all that voters know about the two leaders is that the probabilities that they will be moderate, $\pi_{L M}$ and $\pi_{M H}$, respectively, are in the range between $\lambda$ (the lowest possible probability) and 1 . During the election campaign voters observe the candidates and form an opinion about $\pi_{L M}$ and $\pi_{M H}$.

We can now prove the following proposition:

Proposition I: Majoritarian systems. Given asss. (1) through (5) and (7),

$$
1>\Pi_{M H}=0.5\left(1+\frac{1}{1+\tau_{L M}}\right)>0.5 \text {. }
$$

The proposition states that the probability of $\boldsymbol{M H}$ winning is greater than $50 \%$. How much greater depends inversely on the ratio $\tau_{L M} \equiv 0.5 \bar{T}^{H} / \bar{T}^{M}$. This is the ratio of what $M$ stands to gain, $0.5 \bar{T}^{H}$, if $\boldsymbol{L} \boldsymbol{M}$ does not defect left, to what $M$ loses, $\bar{T}^{M}$, if $\boldsymbol{L} \boldsymbol{M}$ does defect left. The smaller is this relative loss to $M$, the less is the probability of $\boldsymbol{M H}$ winning.

Informal Proof. (i) $L$ will always vote $\boldsymbol{L} \boldsymbol{M}$ because there is some chance of a left deviation, analogously for $H$. Hence the probability of $\boldsymbol{M H}$ winning is equal to the probability of $M$ voting for $\boldsymbol{M H}$. $M$ votes $\boldsymbol{M H}$ if $\pi_{M H}\left(\bar{T}^{H} / 2\right)>\pi_{L M}\left(\bar{T}^{H} / 2\right)-\left(1-\pi_{L M}\right) \bar{T}^{M}$ or alternatively if $\pi_{M H} \tau_{L M}>\pi_{L M}\left(1+\tau_{L M}\right)-1$. Hence, when $\pi_{M H}=\lambda, M$ will be indifferent between the two parties when $\lambda \tau_{L M}=\pi_{L M}\left(1+\tau_{L M}\right)-1$ or $\pi_{L M}=\frac{1+\lambda \tau_{L M}}{1+\tau_{L M}}>\lambda$. Given uniform independent distributions, $\boldsymbol{M H}$ will win $50 \%$ of the time when $\pi_{L M} \in\left(\frac{1+\lambda \tau_{L M}}{1+\tau_{L M}}, 1\right)$ and always

\footnotetext{
${ }^{8}$ An interesting possibility is that $\boldsymbol{L M}$, because it is at an electoral disadvantage, will implement tougher organizational procedures to ensure that its leader is more likely to be perceived as moderate than the leader of the $\boldsymbol{M H}$ party. Conversely, because $\boldsymbol{M H}$ has an electoral advantage it may allow $H$ to have more influence over leadership selections than $L$ in the $\boldsymbol{L M}$ party. This logic would exacerbate the tendency (that our model already implies) for the political space in majoritarian systems to be shifted to the right. For example it is both theoretically conceivable and empirically reasonable to consider the Democratic Party in the United States a center party and the Republican Party a center-right party.
}

when $\pi_{L M} \in\left(\lambda, \frac{1+\lambda \tau_{L M}}{1+\tau_{L M}}\right)$. The probability of the former is $\frac{\tau_{L M}}{1+\tau_{L M}}$ and the probability of the latter $\frac{1}{1+\tau_{L M}}$. Thus the probability of $\boldsymbol{M H}$ winning is

$$
\begin{aligned}
\Pi_{M H} & =0.5 \frac{1-\frac{1+\lambda \tau_{L M}}{1+\tau_{L M}}}{1-\lambda}+\frac{\frac{1+\lambda \tau_{L M}}{1+\tau_{L M}}-\lambda}{1-\lambda} \\
& =0.5 \frac{\tau_{L M}}{1+\tau_{L M}}+\frac{1}{1+\tau_{L M}}=0.5\left(1+\frac{1}{1+\tau_{L M}}\right)
\end{aligned}
$$

Proportional Representation: Explaining the CenterLeft Bias. Under PR, we discuss the simplest case where the "center" party, $\boldsymbol{M}$, is always chosen as the formateur. Using the group preferences and government constraint assumptions (1) through (5) and assumption (6), setting out the coalition bargaining rules, we show first that $\boldsymbol{M}$ will prefer a coalition with $\boldsymbol{L}$ to one with $\boldsymbol{H}$. We will subsequently introduce two further developments: the possibility of $\boldsymbol{M}$ switching, or threatening to switch, to bargain with another party, and the case where the formateur is randomly chosen. Neither of these extensions affect the basic insight.

By contrast to the majoritarian case, $M$ has no concern that $\boldsymbol{M}$ will deviate to the left or right because $\boldsymbol{M}$ is a representative party and maximizes $M$ 's interests in coalition negotiations. Hence $\boldsymbol{M}$ will vote $\boldsymbol{M}$. If $\boldsymbol{M}$ is the formateur it will choose $\boldsymbol{L}$ as coalition partner because $\boldsymbol{L}$ and $\boldsymbol{M}$ can split the total taxable pie $\bar{T}$, whereas if $\boldsymbol{M}$ forms a coalition with $\boldsymbol{H}$ they have to share the pie with $\boldsymbol{L}$ to ensure nonregressivity. More precisely:

Proposition II: PR systems. With assumptions (1) through (6), if the formateur is $\boldsymbol{M}$, it will form a coalition with $\boldsymbol{L}$.

Informal Proof. In an $\boldsymbol{L} \boldsymbol{M}$ coalition, $M$ 's net transfer $p_{L M}^{M}$ is given by $.5 \bar{T}-\bar{T}^{M}=.5\left(\bar{T}^{H}+\bar{T}^{M}\right)-\bar{T}^{M}=$ $.5\left(\bar{T}^{H}-\bar{T}^{M}\right)$, in other words half of the pie less $M$ 's contribution to it. In an $\boldsymbol{M H}$ coalition the pie is reduced by the need to ensure that $L$ gets as large a net transfer as $M$ to ensure nonregressivity (assumption (5)). If $p_{M H}^{M}$ is $M$ 's net transfer, then $p_{M H}^{M}=.5\left(\bar{T}-p_{M H}^{M}\right)-\bar{T}^{M}=$ $\frac{1}{3} \bar{T}-\frac{2}{3} \bar{T}^{M}=\frac{1}{3}\left(\bar{T}^{H}-\bar{T}^{M}\right)$. So $p_{L M}^{M}>p_{M H}^{M}$ and $\boldsymbol{M}$ will choose a coalition with $\boldsymbol{L} \boldsymbol{M}$. The formal proof is in Appendix 1(i)

What if $\boldsymbol{M}$ can switch negotiating partner? Can $\boldsymbol{M}$ then not put pressure on $\boldsymbol{L}$ by threatening to switch to negotiating with $\boldsymbol{H}$ ? For instance, $\boldsymbol{M}$ might say to $\boldsymbol{L}$, "offer me $p_{L M}^{L}=p_{L M}^{M}=\bar{T}^{H} / 2$ " (its ideal policy) "or I'll switch to negotiating with $\boldsymbol{H}$." The answer is that it cannot because the threat of switching is not credible. This is because, if $\boldsymbol{M}$ is bargaining with $\boldsymbol{L}$ and does not switch to bargaining with $\boldsymbol{H}, \boldsymbol{M}$ will get $1 / 2\left(T^{H}-\right.$ $T^{M}$ ), whereas if $\boldsymbol{M}$ switches to bargaining with $\boldsymbol{H}, \boldsymbol{M}$ will only get $1 / 3\left(\bar{T}^{H}-\bar{T}^{M}\right)$. It can also be proved that Proposition II holds even if the formateur can switch bargaining partners repeatedly (the formal proof is in Soskice and Iversen 2005).

It may be objected to Proposition II that, whereas it is empirically true that center parties are more likely to be chosen as formateurs, it is also true that size matters (Warwick 1996). If a pure size principle is used in our case, each party would have an equal chance of 


\begin{tabular}{|c|c|c|}
\hline & $\begin{array}{l}\text { Choose } L M \text { Party } \\
\text { or Coalition }\end{array}$ & $\begin{array}{c}\text { Choose MH Party } \\
\text { or Coalition }\end{array}$ \\
\hline PR system & $1 / 2\left(T^{H}-T^{M}\right)$ & $\frac{1 / 3\left(T^{H}-T^{M}\right)}{2}$ \\
\hline Majoritarian system & $\pi\left(\bar{T}^{H} / 2\right)-(1-\pi) \bar{T}^{M}$ & $\pi\left(\bar{T}^{H} / 2\right)$ \\
\hline
\end{tabular}

being recognized as the formateur (equivalent to the formateur being chosen randomly). But this does not alter the conclusion that $\boldsymbol{L M}$ governments will be more frequent than $\boldsymbol{M H}$ governments. Loosely speaking, the reason is that $\boldsymbol{M}$ will always choose $\boldsymbol{L}$, whereas $\boldsymbol{L}$ is either indifferent between $\boldsymbol{M}$ and $\boldsymbol{H}$ or prefers $\boldsymbol{M}$ to $\boldsymbol{H}$, so that $\boldsymbol{L}$ will choose $\boldsymbol{M}$ at least $50 \%$ of the time. Thus, the likelihood of $\boldsymbol{L} \boldsymbol{M}$ governments must be greater than the likelihood of $\boldsymbol{M H}$ governments. The formal proof is in Appendix 1(ii).

Table 3 summarizes the key results. It shows M's expected payoffs from supporting different parties, or coalitions, depending on the electoral rule. Because we know that $M$ 's party choice determines the outcome of majoritarian elections, and because $M$ 's choice of coalition partner in a PR system determines whether $\boldsymbol{L M}$ governments will be more frequent, the key results of the model are captured by mapping $M$ 's choice of parties or coalition partners.

Note that in a PR system the incentive of $\boldsymbol{M}$ to pick $\boldsymbol{L}$ as a coalition partner follows from the fact that $\boldsymbol{L}$ can never be entirely shut out from sharing in redistributive spending, even when $\boldsymbol{L}$ is not in the coalition. This implies that $\boldsymbol{M}$ has to share with both $\boldsymbol{L}$ and $\boldsymbol{H}$ in an $\boldsymbol{M H}$ coalition, whereas $\boldsymbol{M}$ only has to share with $\boldsymbol{L}$ in an $\boldsymbol{L} \boldsymbol{M}$ coalition. $\boldsymbol{M}$ therefore has a common interest with $\boldsymbol{L}$ in soaking the rich. In a majoritarian system, by contrast, the main concern of $M$ will be to avoid being soaked by the poor. Although both parties will present the same $M$ platform, if there is a chance that $\boldsymbol{L M}$ becomes dominated by $L, \boldsymbol{L M}$ will soak both the rich and the middle class. An $H$-dominated $\boldsymbol{M H}$ party, on the other hand, is constrained by (5) to leave $L$ and $M$ no worse off, and its best option is therefore to cut taxes, and hence its own losses, to zero. With an equal chance $(1-\pi)$ of parties deviating from their electoral platforms, $M$ will therefore be predisposed to support $\boldsymbol{M H}$. The same nonregressivity assumption that leads the middle class to support center-left governments under PR rules thus causes it to support the center-right under majoritarian rules (the shaded cells). The model therefore implies that the electoral system is associated with both government partisanship and levels of redistribution. The next section tests these propositions.

\section{From Model to Structural Estimating Equations}

The purpose of the paper is to show that electoral systems (E) explain the partisan composition of govern- ment $(\mathrm{P})$, and in turn that $\mathrm{P}$ explains redistribution $(\mathrm{R})$. The basic forms of the structural estimating equations are therefore:

$$
\begin{aligned}
& P=f(E) \text { with } f^{\prime}>0 \\
& R=g(P) \text { with } g^{\prime}>0 .
\end{aligned}
$$

Propositions I and II established (SE.1) up to $\operatorname{Pr} L M<$ $\operatorname{Pr} M H$ given $E=$ Majoritarian and $\operatorname{Pr} L M>\operatorname{Pr} M H$ given $E=P R$. (SE.2) clearly holds when redistribution refers to transfers to the poor, and we report results for the poverty rate below. However, we also want to define redistribution more broadly as the percentage change in the Gini coefficients from before to after taxes and transfers. With this definition, it is easy to see that (SE.2) holds when the electoral system is PR since we have already established that $L$ and $M$ are both better off under an $\boldsymbol{L} \boldsymbol{M}$ than under an $\boldsymbol{M H}$ government. It is also the case that $L$ is always better off under an $\boldsymbol{L M}$ government in a majoritarian system as long as there is some probability that $L$ will set policies in the $\boldsymbol{L M}$ party but not in the $\boldsymbol{M H}$ party. On the other hand, if $L$ sets policies in $\boldsymbol{L M}, M$ will be worse off under a centerleft government (which is why $M$ is inclined to vote for $\boldsymbol{M H})$. Whether the Gini falls when going from an $\boldsymbol{L} \boldsymbol{M}$ to an $\boldsymbol{M H}$ government therefore depends on whether the gain to $L$ exceeds the loss to $M$ if the two governments are run by $L$ and $H$, respectively (there are obviously no differences if they are both run by $M$ ). This is clearly the case since $L$ gains $\left(\bar{T}^{H}+\bar{T}^{M}\right)$, whereas $M$ loses $\bar{T}^{M}$. Regardless of whether we focus on redistribution to the poor or overall redistribution in terms of the percentage reduction in the Gini coefficient, therefore, center-left governments always redistribute more than center-right governments.

Note that (SE.2) does not necessarily imply that an $\boldsymbol{L M}$ (or $\boldsymbol{M H}$ ) government redistributes the same under different electoral systems. We cannot say anything about that in general (it depends on $\pi$ ), although there are reasons to expect that $\boldsymbol{L} \boldsymbol{M}$ governments will redistribute more to the poor in a PR system than $\boldsymbol{L M}$ governments in a majoritarian system. We explain why in the discussion of the empirical results for redistribution.

\section{THE EVIDENCE}

We test our argument in two parts. In the first part, we use partisanship and electoral system as explanatory variables to account for differences in the level of redistribution (SE.1). In the second part, we use 
partisanship as the dependent variable, testing the proposition that the electoral system shapes coalition behavior and therefore the composition of governments (SE.2).

\section{Data}

We base our analysis of redistribution on the Luxembourg Income Study (LIS), which has been compiling a large database on pre- and post-tax and transfer income inequality during the past three decades. The LIS data used for this study cover 14 countries from the late 1960s (the first observation is 1967) to the late 1990s (the last observation is 1997). All 14 countries have been democracies since the Second World War. There are a total of 61 observations, with the number of observations for each country ranging from 2 to 7. About one fifth of the observations are from the 1970 s and late 1960 s, about $40 \%$ from the 1980 s, and the remainder from the 1990s. The data are based on separate national surveys, but considerable effort has gone into harmonizing (or "Lissifying") them to ensure comparability across countries and time. The LIS data are widely considered to be of high quality and the best available for the purposes of studying distribution and redistribution (see Brady 2003; OECD 1995).

As noted previously, we use the data specifically to explore the determinants of redistribution as measured by the percentage reduction in the gini coefficient from before to after taxes and transfers. The gini coefficient is perhaps the best summary measure of inequality, and varies from 0 (when there is a perfectly even distribution of income) to 1 (when all income goes to the top decile). Using an adjusted version of the LIS data-constructed by Huber, Stephens, and their asso-

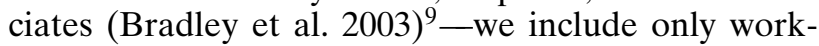
ing age families, primarily because generous public pension systems (especially in Scandinavia) discourage private savings and therefore exaggerate the degree of redistribution among older people. Furthermore, because data are only available at the household level, income is adjusted for household size using a standard square root divisor (see OECD 1995).

On the independent side, the key variables for explaining redistribution are government partisanship and electoral system. The first is an index of the partisan left-right "center of gravity" of the cabinet based on (1) the average of three expert classifications of government parties' placement on a left-right scale, weighted by (2) their decimal share of cabinet portfolios. The index goes from left to right and is standardized vary between 0 and 1 . The measure was conceived by Gross and Sigelman (1984) and has been applied to OECD countries by Cusack in a new comprehensive data set on parties and partisanship (see Cusack and Fuchs 2002 and Cusack and Engelhardt 2002 for details). The expert codings are from Castles and Mair (1984),

\footnotetext{
${ }^{9} \mathrm{We}$ are grateful to the authors for letting us use their data.
}

Laver and Hunt (1992), and Huber and Inglehart (1995).

One issue raised by this measure is how we can be sure that partisan effects are due to differences in "who governs" as opposed to differences in voter preferences. Our argument is that the electoral system affects the party composition of governments, and hence government policies-not that electorates in different countries want different governments and policies (although that might of course also be the case). One way of making sure is to use the difference between the ideological center of gravity of the government and the ideological position of the median voter. Because the position of each party represented in the legislature is known, we can use the position of the party with the median legislator as a proxy for the median voter preference. Hence, we also test our model using this relative center of gravity measure. In cases with single-party majority governments (such as the current British Labour government)-where the government party controls the median legislator by definition - we use the mean position of the legislative parties weighted by the parties' seat shares (so that the Labour government would be recorded as being left of center). ${ }^{10}$

Turning to measurement of electoral system, the theoretical distinction between majoritarian two-party systems and proportional multiparty systems is roughly matched by differences in actual electoral systems (see Table 4). With the partial exception of Austria (because of the strong position of the two main parties), all PR systems tend to have multiple parties and coalition governments, whereas the non-PR systems have few parties and frequent single-party majority governments (although Australia and Ireland have experienced several instances of coalition governments) ${ }^{11}$ This is indicated in the third column of Table 4 using Laasko and Taagepera's (1979) measure of the effective number of parties in parliament. ${ }^{12}$ France is somewhat of an outlier among the majoritarian cases, but the second round of voting in the French runoff system usually involves candidates from only two parties.

The division of countries into two electoral systems is bolstered by the quantitative proportionality measure in the last column. This is a composite index based on Lijphart's measure of the effective threshold of representation and Gallagher's measure of the disproportionality between votes and seats (data are from Lijphart 1994). Note that the index is consistent with the division into a majoritarian and a proportional group: there are no cases that should be "switched" based on their value on the index. All our results

\footnotetext{
${ }^{10}$ We did the same in a small number of cases where the government position is equivalent to the median legislator, but where it is not a single-party majority government.

${ }^{11}$ Ireland is perhaps the most ambiguous case, but it is not part of the redistribution regression, and the results for partisanship are not sensitive to the particular electoral system measure we use or whether Ireland is included or excluded.

12 The effective number of parties is defined as one divided by the sum of the square root of the shares of seats held by different parties (or one divided by the Hilferding index).
} 


\begin{tabular}{|c|c|c|c|}
\hline & Electoral System & $\begin{array}{c}\text { Effective Number } \\
\text { of Legislative } \\
\text { Parties }\end{array}$ & $\begin{array}{c}\text { Proportionality } \\
\text { of Electoral } \\
\text { System }\end{array}$ \\
\hline \multicolumn{4}{|l|}{ Majoritarian } \\
\hline Australia & Majoritya & 2.5 & 0.19 \\
\hline Canada & SMP & 2.2 & 0.13 \\
\hline France & Run-off ${ }^{b}$ & 3.8 & 0.16 \\
\hline Ireland & $\mathrm{STV}^{c}$ & 2.8 & 0.70 \\
\hline Japan & SNTV $^{d}$ & 2.7 & 0.61 \\
\hline New Zealand & SMP & 2.0 & 0.00 \\
\hline UK & SMP & 2.1 & 0.16 \\
\hline USA & SMP & 1.9 & 0.39 \\
\hline Average & & 2.5 & 0.30 \\
\hline \multicolumn{4}{|l|}{ Proportional } \\
\hline Austria & PR & 2.4 & 0.89 \\
\hline Belgium & PR & 5.2 & 0.86 \\
\hline Denmark & PR & 4.4 & 0.96 \\
\hline Finland & PR & 5.1 & 0.87 \\
\hline Germany & PR & 2.6 & 0.91 \\
\hline Italy & PR & 4.0 & 0.91 \\
\hline Netherlands & PR & 4.6 & 1.00 \\
\hline Norway & PR & 3.3 & 0.76 \\
\hline Sweden & PR & 3.3 & 0.90 \\
\hline Average & & 3.9 & 0.90 \\
\hline \multicolumn{4}{|c|}{$\begin{array}{l}\text { a The use of the single transferable vote in single-member constituencies makes the Australian electoral } \\
\text { system a majority rather than plurality system. } \\
\text { b The two-round runoff system has been in place for most of the postwar period with short interruptions of } \\
\text { PR (1945 until early } 1950 \text { s and } 1986-88 \text { ). } \\
\text { cThe Irish single transferable vote system (STV) is unique. Although sometimes classified as a PR system, } \\
\text { the low constituency size (five or less) and the strong centripetal incentives for parties in the system makes } \\
\text { it similar to a median-voter-dominated SMP system. } \\
{ }^{d} \text { The single nontransferable voting (SNTV) in Japan (until 1994) deviates from SMP in that more than one } \\
\text { candidate is elected from each district, but small district size and nontransferability make it clearly distinct } \\
\text { from PR list systems. }\end{array}$} \\
\hline
\end{tabular}

go through if we use this index instead of the PRmajoritarian dichotomy.

We also controlled for variables that are commonly assumed to affect redistribution and/or partisanship. These variables, with definitions, sources, as well as a short discussion of causal logic, are listed next. Country means and a correlation matrix are provided in Appendix 2.

Pretax and Transfer Inequality. This variable is included to capture the Meltzer-Richard logic that more inequality leads to more redistribution. It is measured as the earnings of a worker in the 90th percentile of the earnings distribution as a share of the earnings of the worker with a median income. We are using earnings data, despite their limitations, because the MeltzerRichard model applies to individuals, not households. The data is from OECD's wage dispersion data set (unpublished electronic data).

Constitutional Veto Points. Composite measure of federalism, presidentialism, bicameralism, and the frequency of referenda, based on Huber, Ragin, and Stephen's (1993). The more independent decision nodes, the more veto points. The left in countries with many veto points may have found it harder to overcome opposition to redistributive spending.
Unionization. According to power resource theory, high union density should lead to more political pressure for redistribution and a stronger left, whereas simultaneously reducing primary income inequality. The data are from Visser $(1989,1996)$.

Voter Turnout. Lijphart (1997) argues that there is much evidence to the effect that voter nonturnout is concentrated among the poor. Higher turnout may therefore be associated with less redistribution. The turnout data are from annual records in Mackie and Rose (1993) and in International Institute for Democracy and Electoral Assistance (1997).

Unemployment. Because unemployed receives no wage income, they are typically poor in the absence of transfers. Because all countries have public unemployment insurance, higher unemployment will therefore "automatically" be linked to more redistribution. We use standardized rates from OECD, Labour Force Statistics (Paris: OECD, various years).

Real per capita Income. This is a standard control to capture "Wagner's Law," which says that demand for social insurance is income elastic. The data are expressed in constant 1985 dollars and are from the World Bank's Global Development Network Growth 
Database (http://www.worldbank.org/research/growth/ GDNdata.htm) - itself based on Penn World Table 5.6, Global Development Finance and World Development Indicators.

Female Labor Force Participation. Women's participation in the labor market is likely to affect redistributive spending because it entitles some women to benefits (unemployment insurance, health insurance, etc.) for which they would otherwise be ineligible. Because women tend to be lower paid it may also increase support for the left and for redistributive policies. The measure is female labor force participation as a percentage of the working age population and is taken from OECD, Labour Force Statistics, Paris: OECD, various years.

\section{Statistical Model}

Our starting point for estimating the second structural equation (S.E.2) is a simple error correction model. In this model, current redistribution, $R_{i, t}$, is equal to past redistribution plus a contribution from redistributive partisan policies, $P_{i, t}$ (and potentially other factors), that deviate from policies that would preserve the status quo level of redistribution:

$$
R_{i, t}=\rho \cdot\left[\alpha+\beta \cdot P_{i, t}-R_{i, t-1}\right]+R_{i, t-1}+u_{i, t},
$$

where $\rho$ is speed with which redistribution changes in response to changes in policy, and $u$ is identically and independently distributed with mean 0 and variance $s_{u}^{2}$.

With our data on redistribution, however, we cannot estimate this model directly because the observations on the dependent variable for each country are unequally spaced, varying between 2 and as many as 10 years. To deal with this missing data problem we develop a modified version of the model where we substitute the above expression for $R_{i, t-1}, R_{i, t-2}$, and so forth, until we get to another observation of the lagged dependent variable. This procedure yields the following expression:

$$
\begin{aligned}
R_{i, t}= & \rho \cdot \alpha \cdot \sum_{s=0}^{N}(1-\rho)^{s}+\rho \cdot \beta \cdot \sum_{s=0}^{N}(1-\rho)^{s} \cdot P_{i, t-5} \\
& +(1-\rho)^{N+1} \cdot R_{i, t-N+1}+\sum_{s=0}^{N}(1-\rho)^{s} \cdot u_{i, t-5},
\end{aligned}
$$

or

$$
\begin{aligned}
& R_{i, t}-(1-\rho)^{N+1} \cdot R_{i, t-N+1} \\
& =\rho \cdot \alpha \cdot \sum_{s=0}^{N}(1-\rho)^{s}+\rho \cdot \beta \cdot \sum_{s=0}^{N}(1-\rho)^{s} \\
& \quad \cdot P_{i, t-5}+\sum_{s=0}^{N}(1-\rho)^{s} \cdot u_{i, t-s} .
\end{aligned}
$$

The second term on the right-hand side is a measure of the cumulative effect of partisanship over a period of $N$ years, where $N$ is the gap between the current and previous observation ( $s$ is the lag in years). Of course, in so far as other variables affect redistribution we need to calculate the cumulative effects of these in precisely the same manner as for partisanship. Because we have annual observations for partisanship and all control variables, the estimated model is based on complete time series except for the dependent variable. The model is estimated by choosing a value for $\rho$ that maximizes the explained variance.

Given our assumptions the composite errors are serially uncorrelated, ${ }^{13}$ but because the error term depends on $N$, there is heteroscedasticity. The reported standard errors adjust for such heteroscedasticity, but not for contemporaneous correlation of errors because the latter tends to be inaccurate when there are few observations over time (Wallerstein and Moene 2003). In practice, however, the results are very similar when also adjusting for contemporaneous correlation (known as panel corrected standard errors; see Beck and Katz 1995), and we therefore do not report them here.

The model used to explain partisanship in the second part of the analysis (S.E.1) is a straightforward OLS regression that is explained below.

\section{Findings}

Redistribution. We begin our presentation with the results from estimating a simple baseline model with economic variables only (column 1 in Table 5). As expected, female labor force participation and unemployment are associated with more redistribution. Contrary to Wagner's Law, higher per capita income slightly reduces redistribution, although the result is not statistically significant across model specifications.

As in other studies, we also find that inequality of pretax and transfer earnings has a negative effect on redistribution, contrary to the Meltzer-Richard model expectation. This negative effect is statistically significant at a .01 level, and the substantive impact is strong: a 1 SD increase in inequality is associated with a .3 standard deviation reduction in redistribution.

Yet the effect of inequality reverses (though the positive effect is not significant) when we include controls for the political-institutional variables (columns 2-4). One likely reason for this change is that left governments, as well as strong unions and PR, not only cause an increase in redistribution but also reduce inequality. Ansell (2005), for example, has found strong evidence that left governments spend more on primary education, which is likely to increase the equality of the wage structure. If so, excluding partisanship produces an omitted variable bias on the coefficient for inequality.

$\overline{13}$

$$
E\left(\sum_{s=1}^{N_{1}}\left[(1-\rho)^{s} u_{i, t-s}\right] \cdot \sum_{s=1}^{N_{2}}\left[(1-\rho)^{s} u_{i, t-\left(N_{1}+1\right)^{-s}}\right]\right)=0,
$$

since the errors in the first square bracket run from $u_{i, t}$ to $u_{i, t-N_{1}}$ and in the second from $u_{i, t-\left(N_{1}+1\right)}$ to $u_{i, t-\left(N_{1}+1\right)-N_{2}}$. 


\begin{tabular}{|c|c|c|c|}
\hline & (1) & (2) & (3) \\
\hline Inequality & $\begin{array}{c}-16.75^{* * *} \\
(5.68)\end{array}$ & $\begin{array}{l}13.17 \\
(9.36)\end{array}$ & $\begin{array}{l}12.48 \\
(8.96)\end{array}$ \\
\hline \multicolumn{4}{|l|}{ Political-institutional variables } \\
\hline Government partisanship (right) & - & $\begin{array}{l}-2.38^{* * *} \\
(0.73)\end{array}$ & - \\
\hline $\begin{array}{l}\text { Government partisanship relative to } \\
\text { median legislator }\end{array}$ & - & - & $\begin{array}{l}-2.93^{* * *} \\
(0.75)\end{array}$ \\
\hline Voter turnout & - & $\begin{array}{c}0.01 \\
(0.10)\end{array}$ & $\begin{array}{c}-0.06 \\
(0.10)\end{array}$ \\
\hline Unionization & - & $\begin{aligned} 0.16^{*} \\
(0.09)\end{aligned}$ & $\begin{array}{r}0.15^{*} \\
(0.09)\end{array}$ \\
\hline Number of veto points & - & $\begin{array}{l}-1.57^{* *} \\
(0.62)\end{array}$ & $\begin{array}{l}-1.79^{* * *} \\
(0.59)\end{array}$ \\
\hline Electoral system (PR) & - & $5.00^{* *}$ & $4.44^{* *}$ \\
\hline Controls & & $(2.15)$ & $(2.06)$ \\
\hline Per capita income & $\begin{array}{l}-0.001^{* * *} \\
(0.00)\end{array}$ & $\begin{array}{r}-0.001 \\
(0.00)\end{array}$ & $\begin{array}{c}-0.001 \\
(0.000)\end{array}$ \\
\hline $\begin{array}{l}\text { Female labor force } \\
\text { participation }\end{array}$ & $\begin{array}{l}0.73^{* * *} \\
(0.11)\end{array}$ & $\begin{array}{r}0.36^{*} \\
(0.20)\end{array}$ & $\begin{array}{l}0.45^{* *} \\
(0.20)\end{array}$ \\
\hline Unemployment & $\begin{array}{l}0.81^{* * *} \\
(0.27)\end{array}$ & $\begin{array}{l}0.99^{* * *} \\
(0.27)\end{array}$ & $\begin{array}{l}1.08^{* * *} \\
(0.26)\end{array}$ \\
\hline$\rho$ & .4 & .7 & .7 \\
\hline$R$-squared & 0.648 & 0.746 & 0.765 \\
\hline$N$ & 47 & 47 & 47 \\
\hline \multicolumn{4}{|c|}{$\begin{array}{l}\text { Note: Significance levels: } \text { * }^{* *}<.01 ;^{* *}<.05 ;^{*}<.10 \text { (two-tailed tests). All independent variables are measures of the } \\
\text { cumulative effect of these variables between observations on the dependent variable. See regression equation and } \\
\text { text for details. }\end{array}$} \\
\hline
\end{tabular}

The most important result in Table 5 is that right partisanship has a strong and statistically significant negative effect on redistribution, regardless of whether we use the absolute (column 2) or the relative (column 3) measure of partisanship. A 1 SD shift to the right reduces redistribution by about $1 / 3 \mathrm{SD}$. This confirms previous research, especially that of Bradley et al. (2003), and it adds the finding that partisanship matters even when measured relative to the ideological center of the legislature. This is important to our story because it implies that political parties, and the coalitions they form, matter for redistribution-not just differences in the preferences of electorates.

The results also suggest that multiple veto points, as expected, reduce redistribution, and that PR has a direct (positive) effect on redistribution. The latter effect holds regardless of which measure of electoral system in Table 4 that we use. Our model suggests one possible reason for this because if the probability of left deviation from a median voter platform is not too high, center-left governments will always redistribute more to the poor under PR than under majoritarian rules. To test this, we ran the same model using the percentage reduction in the poverty rate instead of reduction in the gini coefficient as the dependent variable. Consistent with this proposition it turns out that whereas the effect of partisanship is about the same, the direct effect of PR is notably stronger. ${ }^{14}$

\footnotetext{
${ }^{14}$ The effect of going from a majoritarian system to a PR system is to increase redistribution to the poor by $.7 \mathrm{SD}$ whereas the effect on the gini coefficient is .5 SD.
}

There may also be effects of electoral systems that we have not modeled. Persson and Tabellini (2003), for example, have argued that single member plurality systems incentivize politicians to target spending on geographically concentrated constituencies, whereas PR, with ideally only one electoral district, encourages politicians to spend more on universalistic benefit programs. Because universalistic programs are likely to be more redistributive than geographically targeted programs, this would mean that PR has a direct effect on redistribution. But our focus is on the effect of electoral system on partisanship, to which we now turn.

Partisanship. Whereas both government partisanship and electoral system are important in explaining redistribution, partisanship itself is shaped by the distinct coalitional politics associated with different electoral systems. A key implication of our argument is that center-left governments tend to dominate over long periods of time under PR, whereas center-right governments tend to dominate under majoritarian institutions. Although the electoral system has a direct effect on redistribution, we argue that partisanship is one of the key mechanisms through which it exerts an effect on redistribution.

We use the partisan center of gravity $(\mathrm{CoG})$ index as a dependent variable and indicators for party and electoral systems as independent variables. We have data for 18 countries that have been democracies since the Second World War, beginning with the first democratic election after the war and ending in 1998. One country-Switzerland-has a collective executive that 
prevents coalition politics from having any influence on the composition of the government. We therefore exclude this case from the analysis, although every result reported in this section goes through with Switzerland included. ${ }^{15}$

Table 1 presented in the beginning of this paper is a simple cross-tabulation of electoral system and government partisanship using annual observations as the unit of analysis. Governments are coded as being leftof-center if their position on the composite left-right index is to the left of the overall mean. This is somewhat arbitrary because the mean may not correspond to a centrist position. An alternative would be to define the center as the middle of the scale. But in two of the three expert surveys the middle of the scale is not explicitly defined as centrist in terms of an absolute standard, and experts may well equate it instead with the observed center of a party system, whether this center is shifted to the left or right. In practice, this choice has little effect on the results.

Identifying a centrist position, however, is important for a different reason. If an $\boldsymbol{L M}$ leadership party in a majoritarian system is centrist, then the model implies that it stands a good chance of winning. Observing such a party in government is therefore consistent with the model. At the same time it cannot be counted as confirmatory evidence because we do not have any independent measure to determine whether the party platform is credible. The relative frequency of center and center-right governments therefore cannot be hypothesized a priori. Moreover, because our theory implies that the political space in majoritarian systems is tilted to the right (due to strategic voting in a setting of incomplete platform commitment), if we include governments that are centrist in an absolute sense, these would be counted as center-left in terms of their relative position. Because two of the component measures in the CoG index are almost certainly measuring relative positions, the results would therefore be biased against the theory. Our solution is to use one of the component measures in the CoG index by Castles and Mair (1984) to exclude governments that are centrist in the absolute sense. The Castles-Mair measure is the only one that explicitly defines the middle value (3) as a party having a centrist left-right ideology. ${ }^{16}$ All our results also go through if we base the analysis exclusively on the Castles and Mair Scale.

As pointed out in the introduction, in a simple crosstab of electoral system and government partisanship there is only one country, Germany, that does not conform to the predicted pattern. In this case there were 34 years with center-right governments and only 16 years with center-left governments. A possible expla-

\footnotetext{
$\overline{15}$ Because right parties cannot be excluded from government power in Switzerland, we should expect redistribution to be lower than that in other PR countries. This is in fact the case, because the average preto post-tax and transfer reduction in the gini is $9 \%$ in Switzerland, whereas it is $28 \%$ in other PR countries.

${ }^{16}$ We also excluded centrist governments from the PR cases because they neither confirm nor disconfirm the theory (although bias is less of a concern here). In total, 95 out of 734 country-years were coded as centrist on the Castles-Mair (1984) scale.
}

nation is the role of the German Christian Democrats (CDU/CSU). This party is usually seen as a coalition of groups from different locations in the income distribution, where group differences are worked out through intraparty bargaining (as we would expect in a representative party). The Christian Democrats can therefore credibly claim to be closer to the center than a typical conservative party representing mainly highincome voters. This helps explain why the small pivotal liberal party (FDP) chose to ally with CDU/CSU instead of the Social Democratic Party (SPD) in most of the postwar period. But note that even in this special case, government policies are heavily influenced by PR because the right has, in effect, gained access to government power only by accepting a compromise with lower income groups that involves at least some redistribution.

Germany aside, one can question the results in Table 1 for the same reason that was pointed out when using the government center of gravity measure to explain redistribution: it could reflect differences in voter preferences rather than in coalitional party politics. Note, however, that strategic voting in majoritarian systems is expected to shift the legislative center to the right, and the distribution of seats in PR systems should not matter so long as coalitions can be formed that are either to the left or to the right of the center. So evidence on absolute differences in partisanship is clearly relevant to our theory. Still, using the relative measure of partisanship allows us to exclude explanations that emphasize the distribution of voter preferences, and it serves as a useful robustness test. In Table 6, governments are therefore coded as centerleft (center-right), only if they are to the left (right) of the legislative median (or the legislative mean in cases with single party majority governments). This does not change the results very much, although they are (not surprisingly) slightly weaker. About two thirds of governments under PR are now to the left of the legislative median, whereas two thirds of governments under majoritarian institutions are to the right. As before, all but one country conform to this pattern. ${ }^{17}$

What alternative explanations might there be for the pattern observed in Table 6? Because we use the difference between the position of the government and the median legislator, we have limited such alternatives to variables that affect the postelection partisan composition of governments. We thus implicitly "control" for all variables that may affect the distribution of preferences in the electorate. Although there are obviously a plethora of situationally specific factors that shape each instance of government formation, variables that

\footnotetext{
17 The "outlier" is no longer Germany since most governments in that country were in fact to the left of the median, even as they tended to be to the right compared to other PR systems. Instead, the deviant case is France where slightly more than half (29 of 52) of the observations are to the left of the legislative median. This is because the party with the median legislator tends to be very right-wing, whereas French governments sometimes include representation from more moderate parties. The rightist orientation of French politics is also clearly evident in the fact that every president in the postwar period, except for François Mitterrand, has been from a right of center party.
} 


\begin{tabular}{|c|c|c|c|c|}
\hline \multirow{4}{*}{ Electoral System } & & \multicolumn{2}{|c|}{$\begin{array}{l}\text { Government } \\
\text { Partisanship }\end{array}$} & \multirow{2}{*}{$\begin{array}{l}\text { Proportion of Right } \\
\text { Governments }\end{array}$} \\
\hline & & $\overline{\text { Left }}$ & $\overline{\text { Right }}$ & \\
\hline & Proportional & $\begin{array}{c}291 \\
(9)\end{array}$ & $\begin{array}{l}171 \\
(0)\end{array}$ & 0.37 \\
\hline & Majoritarian & $\begin{array}{l}116 \\
(1)\end{array}$ & $\begin{array}{l}226 \\
(7)\end{array}$ & 0.66 \\
\hline
\end{tabular}

would systematically bias the composition of governments in one ideological direction or the other are not easy to think of.

To our knowledge, there are only two candidates for such variables in the existing literature. The first goes back to Rokkan's (1970) well-known explanation for the choice of electoral systems (see also Alesina and Glaeser 2004 and Boix 1999). Rokkan argues that at the time of the extension of the franchise, when a united right faced a rising but divided left, the governing right chose to retain majoritarian institutions. Conversely, when a divided right faced a rising and united left, the response was to opt for PR. If this pattern of fractionalization persisted into the postwar period, the right would tend to have an advantage in majoritarian systems, whereas the left would tend to have an advantage under PR (in the latter case because the transaction costs of bargaining presumably rise with the number of parties). This would produce the pattern that our model predicts, but for different reasons.

A simple test of this argument is to see whether there is a relationship between party fragmentation and electoral system in the expected direction. For this purpose we use a variable in the Cusack-Engelhardt (2002) dataset, which is the difference between party fractionalization on the left and right, where fractionalization is defined the usual way as one minus the sum of the squared seat shares held by parties to the left or to the right of the center (Rae 1968). There is in fact no significant correlation $(\mathrm{r}=-0.15)$, which could either mean that Rokkan was wrong or that the relationship between fractionalization and electoral systems has changed over time. Either way, fractionalization should not affect the relationship between electoral system and partisanship in the period we focus on.

To confirm this, we ran a simple multiple regression, using partisanship as the dependent variable and electoral system and fractionalization as independent variables (see Table 7). ${ }^{18}$ Note that the coefficient for

\footnotetext{
18 Because there is little meaningful variance in electoral systems over time, we simply ran a cross-section regression on the averages from 1950 to 1996 (for which we have complete data on several control variables). It is of course possible, indeed standard, to pool the country time-series while correcting for serial correlation by adding a lagged dependent variable (PCTS). Our results hold up in such a specification-indeed the levels of significance improve notably-but
}

electoral system variable is very similar whether or not fractionalization is included (compare columns 1 and 2). In substantive terms, going from a majoritarian to a PR system shifts the center of gravity of the government by a factor that is roughly equivalent to moving from an average Christian democratic government to a social democratic government or from a conservative government to a Christian democratic government. Not surprisingly, greater fractionalization on the left than on the right does lead to more right-leaning governments on average. But this is not relevant to our story.

The second argument is that vote-seat disproportionalities may favor the right under majoritarian institutions. The explanation would be that the boundaries of electoral districts in majoritarian democracies were drawn up before the full impact of the industrial revolution, which led to an underrepresentation of urban areas where the left had the strongest support (Cox and Katz 2002; Monroe and Rose 2002; Rodden 2005). Although subsequent redistricting may have addressed some of these inequities, they could still play a role in explaining why the left is disadvantaged in majoritarian systems (PR being more unbiased by design). We tested this possibility using a variable that is simply the difference between the legislative seat share of right parties and these parties' share of the vote. It is referred to as "right over-representation" in Table 7.

In contrast to left-right fragmentation, this variable does not register any significant effect, and the sign is in fact in the wrong direction (see column 3). This is somewhat puzzling because there is a positive bivariate correlation between this variable and government partisanship $(\mathrm{r}=.37)$, as well as between this variable and electoral system $(\mathrm{r}=.51)$. The explanation is probably very simple, however. Remember that we are modeling government partisanship, not the governing party's margin of victory. The latter does not matter in majoritarian "winner-take-all" systems. Hence, the only scenario in which the vote-seat disproportionality would affect government partisanship is when the right loses the electoral vote but wins a majority of seats. As illustrated by the British case, such instances are rare. In only one postwar election (1951) did the Conservatives

as demonstrated in Goodrich (2004) it is misleading to use PCTS regressions when nearly all the evidence is cross-sectional. 


\begin{tabular}{|c|c|c|c|c|c|}
\hline & $\begin{array}{c}(1) \\
\text { Government } \\
\text { CoG Minus } \\
\text { Legislative } \\
\text { Median }\end{array}$ & $\begin{array}{c}(2) \\
\text { Government } \\
\text { CoG Minus } \\
\text { Legislative } \\
\text { Median }\end{array}$ & $\begin{array}{c}(3) \\
\text { Government } \\
\text { CoG Minus } \\
\text { Legislative } \\
\text { Median }\end{array}$ & $\begin{array}{c}(4) \\
\text { Government } \\
\text { CoG }\end{array}$ & $\begin{array}{c}(5) \\
\text { Government } \\
\text { CoG }\end{array}$ \\
\hline Constant & $\begin{array}{l}0.653^{* * *} \\
(0.039)\end{array}$ & $\begin{array}{l}0.664^{* * *} \\
(0.033)\end{array}$ & $\begin{array}{l}0.663^{* * *} \\
(0.051)\end{array}$ & $\begin{array}{l}0.501^{* * *} \\
(0.046)\end{array}$ & $\begin{array}{c}0.375 \\
(0.453)\end{array}$ \\
\hline Electoral system (PR) & $\begin{array}{l}-0.173^{* * *} \\
(0.054)\end{array}$ & $\begin{array}{l}-0.147^{* * *} \\
(0.047)\end{array}$ & $\begin{array}{l}-0.184^{* * *} \\
(0.063)\end{array}$ & $\begin{array}{l}-0.174^{* * *} \\
(0.063)\end{array}$ & $\begin{array}{c}-0.176^{* *} \\
(0.077)\end{array}$ \\
\hline $\begin{array}{l}\text { Fragmentation } \\
\text { (left minus right) }\end{array}$ & - & $\begin{array}{l}0.241^{* *} \\
(0.094)\end{array}$ & - & $\begin{array}{c}0.201 \\
(0.116)\end{array}$ & - \\
\hline Right over-representation & - & - & $\begin{array}{l}-0.036 \\
(0.101)\end{array}$ & $\begin{array}{l}0.077 \\
(0.104)\end{array}$ & - \\
\hline Electoral participation & - & - & - & - & $\begin{array}{l}0.001 \\
(0.005)\end{array}$ \\
\hline Unionization & - & - & - & - & $\begin{array}{c}-0.004 \\
(0.003)\end{array}$ \\
\hline Female labor force participation & - & - & - & - & $\begin{array}{c}0.004 \\
(0.004)\end{array}$ \\
\hline $\begin{array}{l}\text { Adj. R-squared } \\
N\end{array}$ & $\begin{array}{c}0.37 \\
17\end{array}$ & $\begin{array}{c}0.54 \\
17\end{array}$ & $\begin{array}{c}0.49 \\
17\end{array}$ & $\begin{array}{c}0.55 \\
17\end{array}$ & $\begin{array}{c}0.49 \\
17\end{array}$ \\
\hline
\end{tabular}

win more seats than Labour despite losing the popular vote, and in another, (1974) Labour in fact came out on top despite getting fewer votes. ${ }^{19}$

The last two columns use the absolute government $\mathrm{CoG}$ measure as the dependent variable, which maximizes the cross-national variance in partisanship. But when entered simultaneously, neither fragmentation nor overrepresentation register a significant effect. The electoral system, on the other hand, continues to have roughly the same impact as before. Finally, the last column tests three variables that may reasonably be expected to affect the distribution of voter preferences, hence, the political center of a country. Predictably, high unionization rates are associated with more leftleaning governments, but the effect is weak and statistically insignificant. Electoral participation and female labor force participation (both of which might be expected to benefit the left) are also insignificant and the signs are in the wrong direction. ${ }^{20}$ The electoral system remains the sole variable with a strong and statistically significant effect.

\footnotetext{
19 The right overrepresentation variable, defined as the difference between right seat and vote shares, overstates the right advantage in the case of Britain. The reason is that the Liberal Party is located between Labour and the Conservatives and always gets fewer seats than votes. As a result both Labour and the Conservatives tend to get more seats than implied by their votes. However, we resisted the temptation to "finesse" the measure to reflect this and other unique national circumstances.

${ }^{20}$ The same is true for other potential variables that we tested such as unemployment, the size of the industrial work force, and income per capita.
}

\section{CONCLUSION}

The details of actual tax-and-spend policies for the purpose of redistribution are complex, but the explanation for redistribution in advanced democracies is arguably fairly simple. We propose here that to a very considerable extent, redistribution is the result of electoral systems and the class coalitions they engender. The contribution of this paper is to provide a very general model that explains the electoral system effect, and to empirically test this model.

To explain redistributive policies under democracy, it is essential to understand that policies are multidimensional and that groups have to form partisan coalitions to govern. Both features of redistributive politics are assumed away in standard political economy models that follow the setup in Meltzer and Richard (1981). In our model, by contrast, there is nothing that prevents the poor from taking from the middle class, or the middle class taking from the rich. This means that the middle class, which tends to decide who governs, has an incentive to ally with the poor to exploit the rich, but also an incentive to support the rich to avoid being exploited by the poor. In a majoritarian two-party system, the latter motive dominates because the middle-class cannot be sure that the poor will not set policies in a center-left leadership party. In a PR system with three representative parties, on the other hand, the first motive dominates because the middle-class party can make sure that a coalition with the left party will not deviate from pursuing their common interest in taxing and redistributing from the rich. The center-right governments therefore tend to dominate in majoritarian systems, whereas the center-left governments tend to dominate in PR systems. 
The argument and findings raise several questions for further research. First, the model may have very different implications for developing democracies if the poor has no collective-action capacity or the rich can threaten coups in such countries. Specifically, if the poor can be ignored when they are not participating in government, this increases the likelihood of center-right governments under PR. It also seems plausible that better measures of differences in the collective action capacity of the poor will explain some of the residual variance in redistribution for rich democracies.

Another major area of research is how to integrate arguments about the role of insurance into the model. Transfer spending not only redistributes but also provides insurance against income loss in the event of unemployment, sickness, and so forth. (Moene and Wallerstein 2001). We have argued elsewhere that there exists a strategic complementarity between such insurance and individuals' decisions to invest in particular types of skills (Estevez, Iversen, and Soskice 2001; Iversen 2005; Iversen and Soskice 2001). Specifically, if the government can credible commit to redistributive spending, it serves as an insurance against the loss of income when specific skills are rendered obsolete by technological and other forms of change. The argument in this paper suggests that PR may be a key commitment mechanism in political economies that depend on workers making heavy investments in highly specific skills.

Third, the model may be expanded to explain changes in partisan advantage over time. Although we have abstracted from differences in the dispersion of the earnings distribution, it may be conjectured that as pre-fisc income inequality grows, middle-class fears of being soaked by the poor also grow in majoritarian systems, whereas their incentive to join the poor in soaking the rich intensifies under PR. Thus, contrary to Meltzer-Richard (1981), rising inequality in majoritarian systems may be associated with a greater advantage for the right. This is in fact what McCarty, Poole, and Rosenthal (forthcoming) find in a new study of polarization and partisanship in the United States. Whether the opposite is true in PR countries is an interesting question for future research.

\section{APPENDIX 1: THE PROBABILITIES OF PARTISAN GOVERNMENTS UNDER PROPORTIONAL REPRESENTATION}

\section{Proof of Proposition II:}

(i) When $M$ is formateur it chooses $L$. The equations underlying the alternating offer bargaining between $\boldsymbol{M}$ and $\boldsymbol{L}$ : $\boldsymbol{M}$ 's offer to $\boldsymbol{L}$ is $s_{M}^{L}=\beta s_{L}^{L}$, where $\beta$ is the common discount factor; and $\boldsymbol{L}$ 's offer to $\boldsymbol{M}$ is $\bar{T}^{H}+\bar{T}^{M}-s_{L}^{L}=$ $\beta\left(\bar{T}^{H}+\bar{T}^{M}-s_{M}^{L}\right)$. Solving these two equations for $s_{M}^{L}$ yields $s_{M}^{L}=\frac{\beta}{1+\beta}\left(\bar{T}^{H}+\bar{T}^{M}\right)$; with $s_{M}^{M}=\frac{1}{1+\beta}\left(\bar{T}^{H}+\bar{T}^{M}\right)$ reflecting $\boldsymbol{M}$ 's first mover advantage. As $\beta \rightarrow 1$ (i.e., the time period between offers goes to zero), $s^{L}=s^{M}=0.5\left(\bar{T}^{H}+\bar{T}^{M}\right)$. Hence, $p_{L M}^{M}=s^{M}-\bar{T}^{M}=0.5\left(\bar{T}^{H}-\bar{T}^{M}\right)$.
The equations underlying the bargaining between $\boldsymbol{M}$ and $\boldsymbol{H}$ have to take into account that the "pie" is reduced to allow a payment to $L$ such that $p^{L}=p^{M}$ as the time period between offers goes to zero. This requires that the reduction is $1 / 3\left(\bar{T}^{H}-\bar{T}^{M}\right)$. $\boldsymbol{M}$ 's offer to $\boldsymbol{H}$ is then $s_{M}^{H}=\beta s_{H}^{H}$ and $\boldsymbol{H}$ 's offer to $\boldsymbol{M}$ is $\bar{T}^{H}+\bar{T}^{M}-1 / 3\left(\bar{T}^{H}-\bar{T}^{M}\right)-s_{H}^{H}=\beta\left(\bar{T}^{H}+\bar{T}^{M}-\right.$ $\left.1 / 3\left(\bar{T}^{H}-\bar{T}^{M}\right)-s_{M}^{H}\right)$ implying

$$
s_{M}^{H}=\frac{\beta}{1+\beta}\left(\frac{2}{3} \bar{T}^{H}+\frac{4}{3} \bar{T}^{M}\right) \rightarrow s^{H}=\frac{1}{3} \bar{T}^{H}+\frac{2}{3} \bar{T}^{M},
$$

and therefore

$$
\begin{gathered}
s_{M}^{M}=\frac{1}{1+\beta}\left(\frac{2}{3} \bar{T}^{H}+\frac{4}{3} \bar{T}^{M}\right) \rightarrow s^{M}=\frac{1}{3} \bar{T}^{H}+\frac{2}{3} \bar{T}^{M} . \\
\text { So } p_{M H}^{M}=s^{M}-\bar{T}_{M H}^{M}=\frac{1}{3}\left(\bar{T}^{H}-\bar{T}^{M}\right),
\end{gathered}
$$

which is indeed equal to $p^{L}$.

(ii). When the formateur is randomly chosen, the minimum ratio of $L M$ coalitions to $L M$ and $M H$ coalitions is 3/5. Since $\boldsymbol{M}$ as formateur always chooses $L$ (see 1(a) above), it is sufficient to show that $\boldsymbol{L}$ chooses $\boldsymbol{M}$ at least half the time if $\boldsymbol{H}$ always chooses $\boldsymbol{M}$. (If $\boldsymbol{L}$ or $\boldsymbol{H}$ choose $\boldsymbol{L} \boldsymbol{H}$ it is considered neutral :- neither left or right). So we focus on the choice of $\boldsymbol{L}$ as formateur and begin by establishing the payoffs to $\boldsymbol{L}$ of an $\boldsymbol{L} \boldsymbol{M}$ and $\boldsymbol{L} \boldsymbol{H}$ coalition:

$\boldsymbol{L M}$ : We have already established that $\boldsymbol{L}$ and $\boldsymbol{M}$ splits the total taxable capacity, so $\boldsymbol{L}$ gets:

$$
p_{L M}^{L}=0.5\left(\bar{T}^{M}+\bar{T}^{H}\right) .
$$

LH: Here there are two cases to consider. In case (a) bargaining is not constrained by assumption (5):

$$
\begin{aligned}
& p_{L H}^{L}=0.5\left(\bar{T}^{M}+\bar{T}^{H}\right) \\
& p_{L H}^{M}=-\bar{T}^{M} \\
& p_{L H}^{H}=0.5\left(\bar{T}^{M}+\bar{T}^{H}\right)-\bar{T}^{H}=0.5\left(\bar{T}^{M}-\bar{T}^{H}\right)
\end{aligned}
$$

It can be seen the condition for assumption (5) holding is $-\bar{T}^{M} \geq 0.5\left(\bar{T}^{M}-\bar{T}^{H}\right)$ or $\bar{T}^{M} \leq \bar{T}^{H} / 3$. If this does not hold, then in case (b) the pie needs to be reduced by $\mathrm{x}$, where $\mathrm{x}$ is now defined by $p_{L H}^{M}=\mathrm{x}-\bar{T}^{M}=p_{L H}^{H}: M$ needs to be given $\mathrm{x}$ to make $M$ 's payoff equal to that of $H$. Hence:

$$
\begin{aligned}
p_{L H}^{H} & =0.5\left(\bar{T}^{H}+\bar{T}^{M}-\left(p_{L H}^{H}+\bar{T}^{M}\right)\right)-\bar{T}^{H}=-\bar{T}^{H} / 3 \\
p_{L H}^{L} & =0.5\left(\bar{T}^{H}+\bar{T}^{M}-\left(p_{L H}^{H}+\bar{T}^{M}\right)\right) \\
& =0.5\left(\bar{T}^{H}+\bar{T}^{M}-\left(-\bar{T}^{H} / 3+\bar{T}^{M}\right)\right)=2 \bar{T}^{H} / 3 .
\end{aligned}
$$

If $\boldsymbol{L}$ is formateur, $\boldsymbol{L}$ is indifferent between $\boldsymbol{L M}$ and $\boldsymbol{L} \boldsymbol{H}$ (a). In $\boldsymbol{L} \boldsymbol{H}$ (b) since the pie is smaller $\boldsymbol{L}$ will have a lower payoff than in case (a) so that $\boldsymbol{L}$ will prefer $\boldsymbol{L M}$ to $\boldsymbol{L H}$ (b).

Proposition II(ii) follows directly from $\boldsymbol{M}$ always choosing $\boldsymbol{L} \boldsymbol{M}$, and $\boldsymbol{L}$ choosing $\boldsymbol{L} \boldsymbol{M}$ at least half the time. Only $\boldsymbol{H}$ will choose $\boldsymbol{M H}$, so the maximum probability of $\boldsymbol{M H}$ is $1 / 3 \mathrm{rd}$ Hence, the minimum probability that $\boldsymbol{L} \boldsymbol{M}$ will be chosen is $1 \times 1 / 3+1 / 2 \times 1 / 3=1 / 2$. And the maximum probability that $\boldsymbol{M H}$ will be chosen is $1 / 3$. Hence, the minimum proportion of $\boldsymbol{L M}$ coalitions relative to $\boldsymbol{L M}$ and $\boldsymbol{M H}$ coalitions is $3 / 5$. 


\section{APPENDIX 2: SUMMARY STATISTICS}

\section{TABLE A1. Country Means for Variables Used in Regression Analysis}

\begin{tabular}{|c|c|c|c|c|c|c|c|c|c|c|c|c|}
\hline & $\begin{array}{l}\text { Redistribution } \\
\text { (reduction } \\
\text { (in Gini) }\end{array}$ & $\begin{array}{l}\text { Inequality } \\
\text { (wages) }\end{array}$ & $\begin{array}{l}\text { Partisanship } \\
\text { (right) }\end{array}$ & $\begin{array}{l}\text { Voter } \\
\text { Turnout }\end{array}$ & $\begin{array}{l}\text { Union- } \\
\text { ization }\end{array}$ & $\begin{array}{l}\text { Veto } \\
\text { Points }\end{array}$ & $\begin{array}{c}\text { Electoral } \\
\text { System } \\
\text { (PR) }\end{array}$ & $\begin{array}{c}\text { Left } \\
\text { Frag- } \\
\text { mentation }\end{array}$ & $\begin{array}{c}\begin{array}{c}\text { Right } \\
\text { over- }\end{array} \\
\text { Representaion }\end{array}$ & $\begin{array}{c}\text { Per } \\
\text { capita } \\
\text { Income }\end{array}$ & $\begin{array}{c}\text { Female } \\
\text { Labor } \\
\text { Force } \\
\text { Participation }\end{array}$ & Unemployment \\
\hline Australia & 23.97 & 1.70 & 0.47 & 84 & 46 & 3 & 0 & -0.39 & 0.10 & 10909 & 46 & 4.63 \\
\hline Austria & - & - & 0.30 & 87 & 54 & 1 & 1 & -0.18 & 0.04 & 8311 & 51 & 2.76 \\
\hline Belgium & 35.56 & 1.64 & 0.36 & 88 & 48 & 1 & 1 & -0.34 & 0.27 & 8949 & 43 & 7.89 \\
\hline Canada & 21.26 & 1.82 & 0.36 & 68 & 30 & 2 & 0 & 0.18 & -0.11 & 11670 & 48 & 6.91 \\
\hline Denmark & 37.89 & 1.58 & 0.35 & 84 & 67 & 0 & 1 & -0.40 & 0.07 & 9982 & 63 & 6.83 \\
\hline Finland & 35.17 & 1.68 & 0.30 & 79 & 53 & 1 & 1 & -0.18 & 0.09 & 8661 & 66 & 4.48 \\
\hline France & 25.36 & 1.94 & 0.40 & 66 & 18 & 1 & 0 & 0.10 & 0.09 & 9485 & 51 & 4.57 \\
\hline Germany & 18.70 & 1.70 & 0.39 & 81 & 34 & 4 & 1 & -0.13 & 0.15 & 9729 & 51 & 4.86 \\
\hline Ireland & - & - & 0.42 & 75 & 48 & 0 & 0 & -0.33 & 0.70 & 5807 & 37 & 9.09 \\
\hline Italy & 12.13 & 1.63 & 0.37 & 93 & 34 & 1 & 1 & 0.20 & 0.08 & 7777 & 38 & 8.12 \\
\hline Japan & - & - & 0.78 & 71 & 31 & 1 & 0 & 0.22 & 0.28 & 7918 & 56 & 1.77 \\
\hline Netherlands & 30.59 & 1.64 & 0.31 & 85 & 33 & 1 & 1 & 0.18 & -0.36 & 9269 & 35 & 4.62 \\
\hline New Zealand & - & - & 0.43 & 85 & 23 & 0 & 0 & -0.40 & 0.98 & - & 47 & - \\
\hline Norway & 27.52 & 1.50 & 0.15 & 80 & 54 & 0 & 1 & -0.02 & -0.32 & 9863 & 52 & 2.28 \\
\hline Sweden & 37.89 & 1.58 & 0.17 & 84 & 67 & 0 & 1 & -0.40 & -0.03 & 9982 & 63 & 6.83 \\
\hline U.K. & 22.67 & 1.78 & 0.52 & 76 & 42 & 0 & 0 & 0.08 & 0.07 & 9282 & 54 & 5.01 \\
\hline U.S. & 17.60 & 2.07 & 0.40 & 56 & 23 & 5 & 0 & 0.00 & -0.17 & 13651 & 53 & 5.74 \\
\hline
\end{tabular}

\section{TABLE A2. Correlation Matrix}

\begin{tabular}{|c|c|c|c|c|c|c|c|c|c|c|c|}
\hline & (1) & (2) & (3) & (4) & (5) & (6) & (7) & (8) & (9) & $(10)$ & $(11)$ \\
\hline (1) Redistribution & 1 & & & & & & & & & & \\
\hline (2) Inequality & -0.38 & 1 & & & & & & & & & \\
\hline (3) Partisanship & -0.50 & 0.37 & 1 & & & & & & & & \\
\hline (4) Turnout & 0.11 & -0.38 & -0.24 & 1 & & & & & & & \\
\hline (5) Unionization & 0.75 & -0.22 & -0.49 & 0.51 & 1 & & & & & & \\
\hline (6) Veto points & -0.44 & -0.01 & 0.33 & -0.43 & -0.56 & 1 & & & & & \\
\hline (7) Electoral system & 0.34 & -0.54 & -0.66 & 0.71 & 0.49 & -0.27 & 1 & & & & \\
\hline (8) Left fragmentation & -0.57 & -0.09 & 0.14 & -0.27 & -0.76 & 0.14 & -0.18 & 1 & & & \\
\hline (9) Right overrepresentation & -0.13 & 0.66 & 0.46 & 0.10 & 0.14 & -0.16 & -0.24 & -0.48 & 1 & & \\
\hline (10) Per capita income & 0.12 & -0.42 & -0.08 & -0.51 & -0.18 & 0.61 & -0.22 & 0.08 & -0.64 & 1 & \\
\hline (11) Female LF participation & 0.80 & -0.45 & -0.28 & -0.19 & 0.48 & -0.06 & 0.17 & -0.37 & -0.168 & 0.38 & 1 \\
\hline (12) Unemployment & -0.49 & 0.55 & 0.52 & 0.06 & -0.20 & 0.01 & -0.20 & 0.02 & 0.63 & -0.41 & -0.51 \\
\hline
\end{tabular}

\section{REFERENCES}

Aarts, Kees, André Blais and Hermann Schmitt. Forthcoming Political Leaders and Democratic Elections. Oxford: Oxford University Press.

Acemoglu, Daron, and James Robinson. 2005. Political Origins of Dictatorship and Democracy. Cambridge: Cambridge University Press.

Aldrich, John. 1993. "Rational Choice and Turnout." American Journal of Political Science 37: 246-78.

Aldrich, John. 1995. Why Parties? The Origins and Transformation of Party Politics in America. Chicago: University of Chicago Press.

Alesina, Alberto, and Edward Glaeser. 2004. Fighting Poverty in the US and Europe: A World of Difference. Oxford: Oxford University Press.

Ansell, Ben. 2005. "From the Ballot to the Blackboard? Partisan and Institutional Effects on Human Capital Policy in the OECD. Department of Government." Harvard University. Typescript.

Austen-Smith, David. 2000. "Redistributing Income Under Proportional Representation." Journal of Political Economy 108 (6): 1235-69.

Bawn, Kathleen, and Frances Rosenbluth. 2006. "Coalition Parties versus Coalitions of Parties: How Electoral Agency Shapes the Political Logic of Costs and Benefits." American Journal of Political Science 50 (2): [page nos still pending].
Beck, Nathaniel, and Jonathan Katz. 1995. "What to Do (and Not to Do) with Time-Series Cross-Section Data." American Political Science Review 89 (September): 634-48.

Bénabou, Roland. 1996. "Inequality and Growth." In National Bureau of Economic Research Macro Annual, ed. Ben S. Bernanke and Julio J. Rotemberg, Cambridge: MIT Press, Vol. 11, pp. 11-74.

Besley, Timothy, and Stephen Coate. 1997. "An Economic Model of Representative Democracy." Quarterly Journal of Economics 112 (1): 85-114.

Boix, Carles. 1998. Political Parties, Growth and Equality. New York: Cambridge University Press.

Boix, Carles. 1999. "Setting the Rules of the Game: The Choice of Electoral Systems in Advanced Democracies." American Political Science Review 93: 609-24.

Bradley David, Evelyn Huber, Stephanie Moller, François Nielsen, and John Stephens. 2003. "Distribution and Redistribution in Postindustrial Democracies." World Politics 55 (2): 193-228.

Brady, David. 2003. "Rethinking the Sociological Measure of Poverty." Social Forces 81 (3): 715-52.

Castles, Francis, and Peter Mair. 1984. "Left-Right Political Scales: Some Expert Judgments." European Journal of Political Research 12: 73-88.

Cox, Gary W., and Jonathan N. Katz. 2002. Elbridge Gerry's Salamander: The Electoral Consequences of the Reappointment Revolution. Cambridge: Cambridge University Press. 
Curtice, Cusack, Thomas R., and Lutz Engelhardt. 2002. "The PGL File Collection: File Structures and Procedures." Wissenschaftszentrum Berlin für Sozialforschung.

Cusack, Thomas R., and Susanne Fuchs. 2002. "Documentation Notes for Parties, Governments, and Legislatures Data Set." Wissenschaftszentrum Berlin für Sozialforschung.

Downs, Anthony. 1957. An Economic Theory of Democracy. New York: Harper.

Estevez-Abe, Margarita, Torben Iversen, and David Soskice. 2001. "Social Protection and the Formation of Skills: A Reinterpretation of the Welfare State." In Varieties of Capitalism: The Institutional Foundations of Comparative Advantage, ed. Peter A. Hall and David Soskice, Oxford: Oxford University Press.

Goodrich, Benjamin. 2004. "Problems with and Solutions for TwoDimensional Models of Continuous Dependent Variables." Department of Government, Harvard University. Typescript.

Gross, Donald A., and Lee Sigelman. 1984. "Comparing Party Systems: A Multidimensional Approach." Comparative Politics 16: 463-79.

Hibbs, Douglas. 1977. "Political Parties and Macroeconomic Policy." American Political Science Review 71 (December): 1467-87.

Hicks, Alexander, and Duane Swank. 1992. "Politics, Institutions, and Welfare Spending in Industrialized Democracies, 1960-82." American Political Science Review 86 (3): 649-74.

Huber, Evelyn, Charles Ragin, and John Stephens. 1993. "Social Democracy, Christian Democracy, Constitutional Structure and the Welfare State." American Journal of Sociology 99 (3): 711-49.

Huber, Evelyne, and John D. Stephens. 2001. Development and Crisis of the Welfare State: Parties and Policies in Global Markets. Chicago: University of Chicago Press.

Huber, John D., and Ronald Inglehart. 1995. "Expert Interpretations of Party Space and Party Locations in 42 Societies." Party Politics 1: 73-111.

International Institute for Democracy and Electoral Assistance. 1997. Voter Turnout from 1945 to 1997: A Global Report on Political Participation. Stockholm: IDEA Information Services.

Iversen, Torben. 2005. Capitalism, Democracy and Welfare. Cambridge: Cambridge University Press.

Iversen, Torben, and David Soskice. 2001. "An Asset Theory of Social Policy Preferences.” American Political Science Review 95 (4): 87593.

Kedar, Orit. 2003. Balancing the Seesaw: Ph.D. Dissertation, Harvard University 2003

Kitschelt, Herbert. 1994. The Transformation of European Social Democracy. Cambridge: Cambridge University Press.

Korpi, Walter. 1983. The Democratic Class Struggle. London: Routledge \& Kegan Paul.

Korpi, Walter. 1989. "Power, Politics, and State Autonomy in the Development of Social Citizenship-Social Rights During Sickness in 18 OECD Countries Since 1930." American Sociological Review 54 (3): 309-28.

Kwon, Hyeok Yong, and Jonas Pontusson. 2003. "The Zone of Partisanship. Parties, Unions and Welfare Spending in OECD Countries, 1962-99." Unpublished Manuscript, Department of Political Science, Cornell University.

Laasko, Markku, and Rein Taagepera. 1979. "Effective Number of Parties: A Measure with Applications to Western Europe." Comparative Political Studies 12 (3): 3-27.

Laver, Michael, and W. Ben Hunt. 1992. Policy and Party Competition. New York: Routledge.

Lijphart, Arend. 1994. Electoral Systems and Party Systems: A Study of Twenty-Seven Democracies, 1945-90. New York: Oxford University Press.

Lijphart, Arend. 1997. "Unequal Participation: Democracy's Unresolved Dilemma." American Political Science Review 91: 1-14.

Mackie, Thomas T., and Richard Rose. 1991. The International Almanac of Electoral History, 3rd edition. London: Macmillan.

McCarty, Nolan, Kieth Poole, and Howard Rosenthal. 2006. Polarized America: The Dance of Ideology and Unequal Riches. Cambridge: MIT Press.

Meltzer, Allan H., and Scott. F. Richard. 1981. "A Rational Theory of the Size of Government." Journal of Political Economy 89: 914-27.
Milanovic, Branko. 2000. "The Median-Voter Hypothesis, Income Inequality, and Income Redistribution: An Empirical Test with the Required Data." European Journal of Political Economy 16: 367-410.

Moene, Karl Ove, and Michael Wallerstein. 2001. "Inequality, Social Insurance and Redistribution." American Political Science Review 95 (4): 859-74.

Monroe B. L., and A. G. Rose. 2002. "Electoral Systems and Unimagined Consequences: Partisan Effects of Districted Proportional Representation." American Journal of Political Science 46 (1): $67-$ 89

OECD. 1995. "Income Distribution in OECD Countries: Evidence from the Luxembourg Income Study." Social Policy Studies No. 18.

Osberg, Lars, Timothy Smeeding, and Jonathan Schwabisch. 2003. "Income Distribution and Public Social Expenditure: Theories, Effects, and Evidence." Typescript.

Osborne Martin J., and Al Slivinski. 1996. "A Model of Political Competition with CitizenCandidates." Quarterly Journal of Economics 111 (1): 65-96.

Perotti, Roberto. 1996. "Growth, Income Distribution and Democracy: What the Data Say." Journal of Economic Growth 1 (2): 149-87.

Persson, Torsten, and Guido Tabellini. 1999. "The Size and Scope of Government: Comparative Politics with Rational Politicians." European Economic Review 43: 699-735.

Persson, Torsten, and Guido Tabellini. 2000. Political Economics: Explaining Economic Policy. Cambridge: MIT Press.

Persson, Torsten, and Guido Tabellini. 2003. The Economic Effects of Constitutions MIT Press.

Persson, Torsten, Gerard Roland, and Guido Tabellini. 2004. "How Do Electoral Rules Shape Party Structures, Government Coalitions, and Economic Policies?" CESifo Working Paper Series No. 1115; IGIER Working Paper No. 251.

Powell, Bingham. 2002. "PR, the Median Voter, and Economic Policy: An Exploration." Paper presented at the 2002 Meetings of the American Political Science Association, Boston.

Ross, Michael. 2005. "Does Democracy Reduce Infant Motality?" Paper presented in Workshop on Democratic Institutions and Economic Performance. Duke University. April 1-2, 2005.

Rae, Douglas. 1968. "A Note on Fractionalization of Some European Party Systems." Comparative Political Studies 1: 413-418.

Rodden, Jonathan. 2005. "Red States, Blue States, and the Welfare State: Political Geography, Representation, and Government Policy Around the World.” Typescript, Department of Political Science, MIT.

Roemer, John. 2004. "Does Democracy Engender Equality?" In Political Knowledge and the Public Interest, ed. Edward J. Mansfield and Richard Sisson. Columbus: The Ohio State University Press.

Rogowski Ronald, and Mark Andreas Kayser. 2002. "Majoritarian Electoral Systems and Consumer Power: Price-level Evidence from the OECD Countries." American Journal of Political Science 46 (3): 526-39.

Rokkan, Stein. 1970. Citizens, Elections, Parties: Approaches to the Comparative Study of the Processes of Development. Oslo: Universitetsforlaget.

Schlesinger, James. 1984. "On the Theory of Party Organization." Journal of Politics 46, 369-400.

Soskice, David, and Torben Iversen. 2005. "Why Governments Diverge From the Preferences of the Median Legislator." Department of Government, Harvard University. Typescript.

Visser, Jelle. 1989. European Trade Unions in Figures. Deventer/Netherlands: Kluwer Law and Taxation Publishers.

Visser, Jelle. 1996. "Unionization Trends Revisited.” Mimeo, University of Amsterdam.

Warwick, P. V. 1996. "Coalition Government Membership in West European Parliamentary Democracies." British journal of Political Science 26 (4): 471-99.

Wallerstein, Michael, and Karl Ove Moene. 2003. "Earnings Inequality and Welfare Spending: A Disaggregated Analysis." World Politics 55 (4): 485-516. 
